تأثير اندازهٔ ماهى و تغييرات فصل روى هورمونهاى استروئيدى كنادى در مولدين

$$
\begin{aligned}
& \text { اردك ماهى }
\end{aligned}
$$

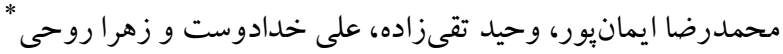

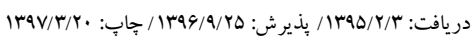

$$
\begin{aligned}
& \text { گُروه شيلات، دانشكده شيلات و محيط زيست، دانشگاه علوم كشاورزى و منابع طبيعى، گر گان، ايران } \\
& \text { zahra.roohi@gau.ac.ir :مسئول مكاتبات }
\end{aligned}
$$

$$
\begin{aligned}
& \text { קكيده. هورمونهاى جنسى استروئيدى نقش مهمى در بسيارى از فرآيندهاى فيزيولوزيكى و بهويزه در توليد مثل ماهيـان استخوانى دارد. بنابر اين مطالعـه هورمسونهـاى }
\end{aligned}
$$

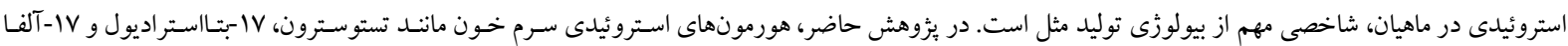

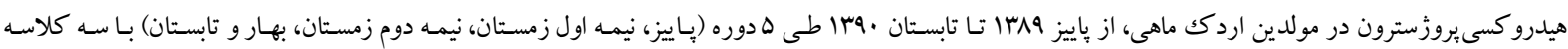

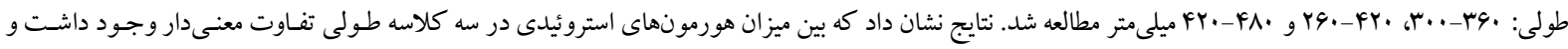

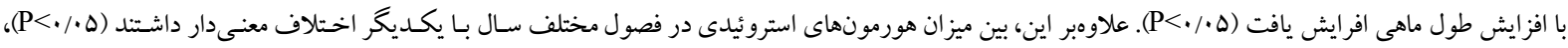

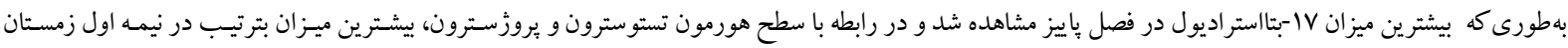

$$
\begin{aligned}
& \text { و نيمهدوم زمستان مشاهده شد. } \\
& \text { وازههاى كليدى. آبزيان، استراديول، يروزسترون، تستوسترون، توليدمثل }
\end{aligned}
$$

\title{
Effect of fish size and seasonal changes on gonadal steroid hormones in pike brood stocks (Esox lucius)
}

\author{
Mohammad Reza Imanpoor, Vahid Taghizadeh, Ali Khodadoust \& Zahra Roohi* \\ Received 22.04.2016/ Accepted 16.12.2017/ Published 10.06.2018
}

Fisheries Sciences, Department of Fisheries and Environment, Gorgan University of Agricultural Science and Natural Resources, Gorgan, Iran.

"Correspondent author: zahra.roohi@gau.ac.ir

\begin{abstract}
Sex steroid hormones play important roles in many physiological processes, particularly in the reproduction of vertebrates. Therefore, the study of steroid hormones in pike is one of the important indicators of reproductive biology. In the present research, serum steroid hormones such as testosterone (T), 17 $\beta$-estradiol (E2) and progesterone (P) in Esox Lucius brood stocks, during one year, in five periods from autumn 2010 to summer 2011 (autumn, first half of winter, second half of winter, spring and summer) with three longitudinal classes (300-360, 360-420 and 420-480 millimeters), were studied. The results showed significant differences between levels of steroid hormones in three longitudinal classes and showed an increasing trend by increased length $(\mathrm{P}<0.05)$. In addition, there were significant differences between levels of gonadal steroid hormones and different seasons $(\mathrm{P}<0.05)$. The highest level of $17-\beta$ estradiol was observed in autumn season. As for testosterone and progesterone hormones, the highest levels were recorded in the first and the second halves of winter.
\end{abstract}

Keywords. aquatic, estradiol, progesterone, reproduction, testosteron 
(Shafiei Sabet, 2008)، تغييرات فصلى هورمونهـاى جنسى در ، هامور خالقرمز (Li et al., 2007)، نوسانات هورمونهـاى جنسى

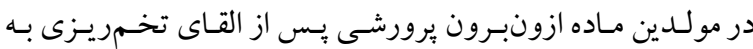
وسـيله Yooneszadeh et al., 2008)GnRH) و جرخــه هورمونهاى استروئيدى در طول مراحل تكامـل تخمـدان در هـامور (Abbasi et al., 2008) اردكك مـاهى (Esox lucius) از ماهيـانى اسـت كـه داراى

ارزش اقتصـادى زيـادى اسـت ( Vosoughi \& Mostajir, 2000). طبق بررسىهاى انجام شده در استانهـاى شـمالى كشـور در

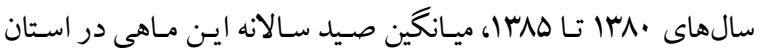

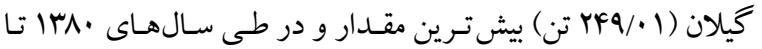

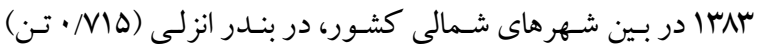
بـالاترين مقـدار بـوده اسـت (Abdali \& Naderi, 2008). زمـان تخمريزى اردكك ماهى تقريباً از اواخـر بهمـن تـا اواسط ارديبهشت

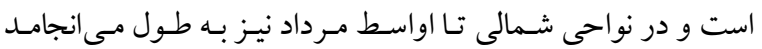

.(Vosoughi \& Mostajir, 2000) با توجه به اينكه كنتـرل هورمـونى بـهـنـوان يـك ابـزار كارامـــ جهـت تكثيـر و يـرورش آبزيـان بـهــار مـىرود، لـذا هـدف از ايـن

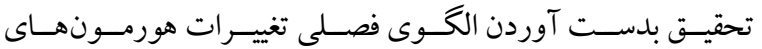

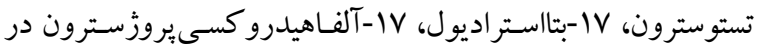
طى روند بلوغ و تخمريزى و همجنـين ارتبـاط آنها بـا انـدازهُ مـاهى در مولدين اردككماهى است.

زمان و محل تهيّه ماهى: ماهى هـا در مقـاطع زمـانى مختلـف طى لى

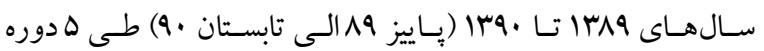

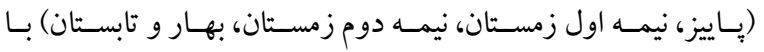

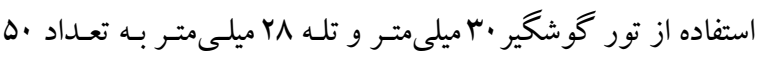
قطعه به صورت تصادفى در نقاط مختلف تالاب انزلى صيد شدند. روشهاى مطالعه بيـومترى: بـراى ايـن منظـور در آزمايشـاه ماهيـان وزن شـده (بـا دقـت ا خرم) و طـول كـل (بـا دقـت انـدازهيـرى 1 ميلىمتر ) اندازه كيرى و ثبت شد.

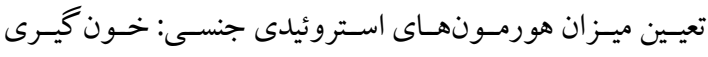
مولدين توسط سرنگك از ساقه دمى صورت گرفته و بـه محفظههــاى حاوى مو اد ضد انعقاد خون منتقـل و سـبس بـا اسـتفاده از سـانتريفيوز
مقلمه

ارزيابى و تشخيص وضعيت فيزيولـوزيكى مـاهى و تعيـين ميـزان و اندازه آن براى توليد مثل مصسنوعى و ايجـاد بهتـرين شـر ايط رشـــ جهت حفظ ذخاير ماهيـان، لازم و ضـرورى اسـت ( Zaprudnova Prozorovskaya, 1999 P Pورمـونهـاى اسـتروئيدى نقـش مهمسى در بسـيارى از فراينـدهاى فيزيولـوزيكى و بـهويـزّه در توليـد مثـل مهرهدار ان دارد (Taghizadeh et al., 2013). مطالعـات

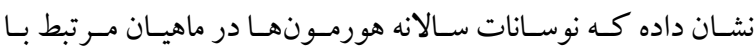
Matty, سيكلهـاى توليـد مثلى، تغذيسهاى و رشـد در آنهاسـت (1985; Pavlidis et al., 2000 . ترشـح كنادوترويين بـهوسيله

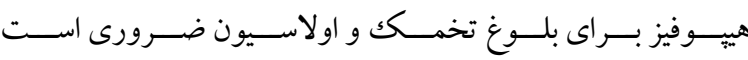
(Nagahama, 1994). در ماهيـان اسـتخوانى، تحـت تـأثير عمـل كُادوتروبين، هورمونهاى استروئيدى V| إبتـاسـتراديول، ||-كتـا-

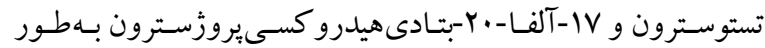
فـراوان در بافـتهـاى گنـادى توليـــ مسىشـود كـهـ بــراى مراحـل كامتوزنز ضرورى هستند )

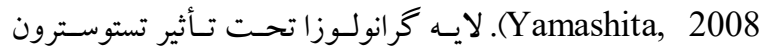
ترشـح شــده از لايسه تكـا، بـهمنظـور توليـــ هورمـون اسـتروئيدى (اسـتراديول) تحريـك مسىشـود. هورمـون VIV-بتـا اسـتراديول باعـث تحريك سنتز و ترشح ويتلوزنين در كبد و تجمع آن در اووسيتهـا مىشود. در واقع فعاليـت آروماتـاز لايـه كرانولـوزا در دورهى زرده -

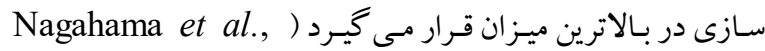
1991 \& 1993; Aremen \& Gay, 2000; Semenkova et (al., 2002; Berg et al., 2005; Drummond, 2006 بسيارى از گونههـا طـى ويتلـوزنز ميـزان اسـتروزن پِاسـما و بـهويـزه

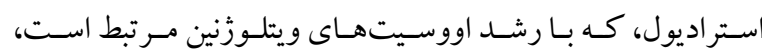
افـزايش يافته اسـت (Katz \& Eckestein, 1974). مطالعـات بسـيارى روى جرخـه هورمـونهـاى جنسى در طـول فراينــ بلـوغ و

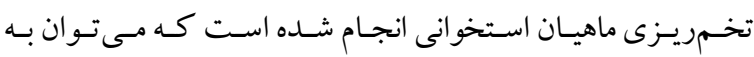
مطالعات انجـام شــده روى تغييـرات فصـلى تيروئيــــ و هورمـونهـاى

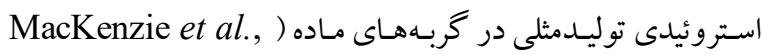
1989)، جر خه تكامل گنادى و ميزان هورمـونهـاى جنسى بِلاسـما در هـامور (Johnson et al., 1998)، ارزيـابى فيزيولـوزى توليـد مثلى در تن زرد بالـه ( Poortenaar et al., 2001)، تأثير انسدازهى مـاهى روى هورمـونهـاى اسـتروئيدى مـاهى سـفيد دريـاى خـزر 


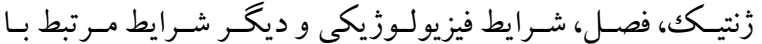

Yousefian et al., 2010; Yousefian ) توليدمثل بستخگى دارد

.\& Laloei, 2011

در اين مطالعه، ميز ان هورمون VIV-بتـاسـتراديول، تستوسترون و IV آ آلفـا هيدرو كسى يروزَسترون در بين سـه كلاسه طولى داراى اختلاف معنى دار مستقيم بوده و بـا افزايش طول مـاهى، افز ايش بافته است كـه بـانتايج Shafiei Sabet و همكاران (2008) روى

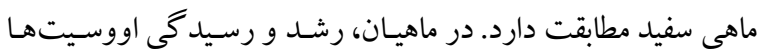

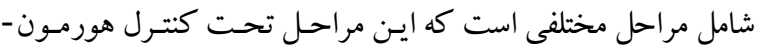

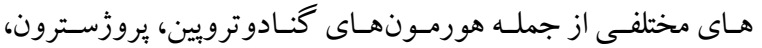
تستوسترون و استراديول است (Lee \& Yang, 2002). در طول رشد و نمو اووسيتها، هورمونهـاى گنـادوترويينى باعث تحريكك تخمــدان و سـبس توليــد هورمـون VIا-بتـاسـتر اديول مسىشـوند و

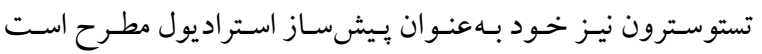
Kousha et al., 2009). استراديول، ويتلـوزنزيز رادر ماهيـان

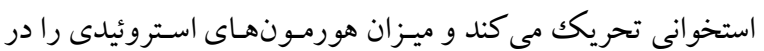
طول بلوغ گناد تغيير مسدهــ (Silversand et al., 1993). بـه -

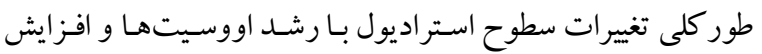
شاخص كنادوسوماتيكك مرتبط است. در ماهى هـا، ميزان استر اديول

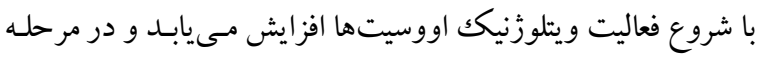

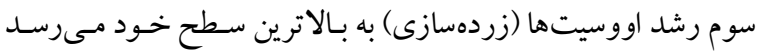

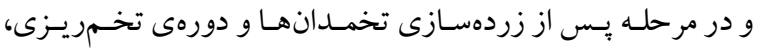
شروع به كاهش مىنمايد (Lee \& Yang, 2002). در يزوهش حاضر، تغييرات سطوح Vا-بتااستراديول در مراحل

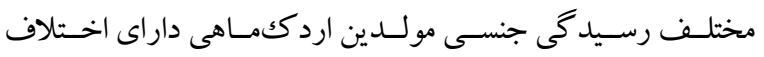

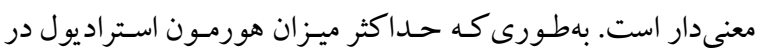

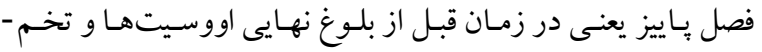

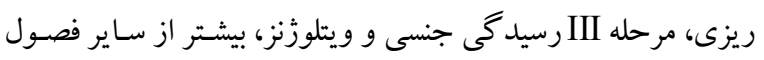

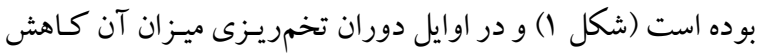

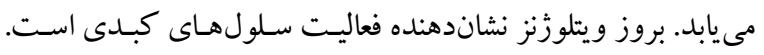

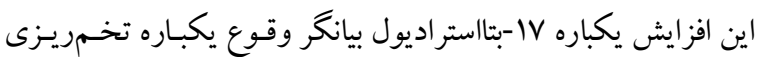

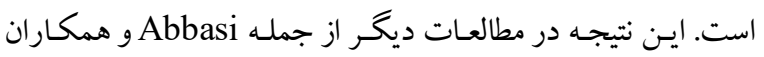

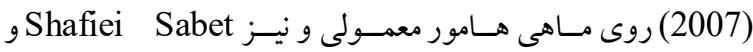
همكاران (2008) روى مـاهى سـفيد دريـاى خـزر بـه اثبـات رسـيده

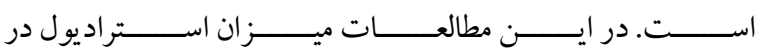

كردن آنها سرم خون گرفنه و توسط جعبـه يونوليـت حاوى يـخ بـهـ

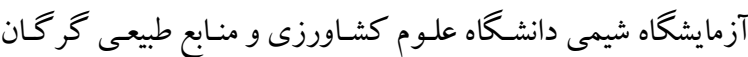
انتقال داده شد. سبس هو رمونهاى موجـود در سرم توسط دستئكاه الايزا و كيتهاى هورمونى DRG اندازه كيرى شدند.

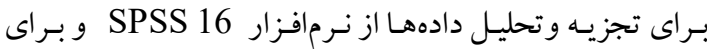
رسم نمودارها از برنامه Excel استفاده شد. بهمنظور مقايسه آمارى

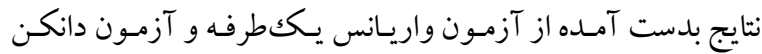

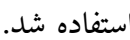

نتايج نتايج تحقيق در نمودارهـاى شـكل هـاى ا تـا ونشـان داده شـده

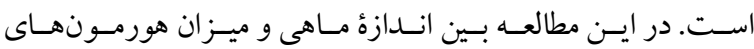

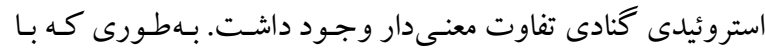

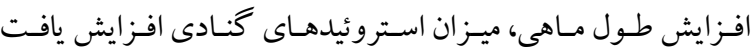

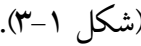

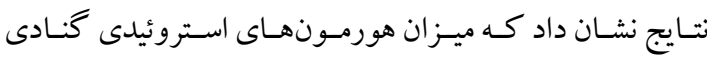
مولدين اردكك در فصول مختلف تفاوت معنسدارى وجـود داشـت.

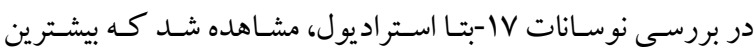

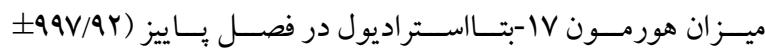

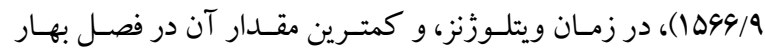

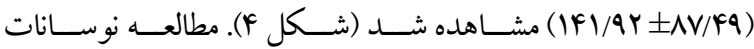

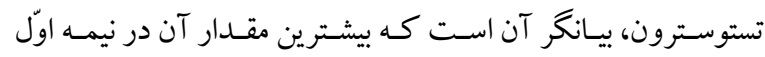

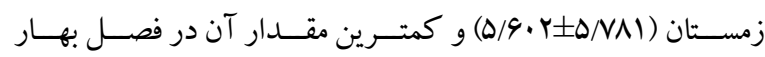
( ) (

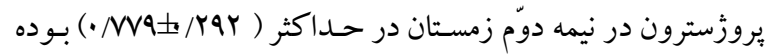

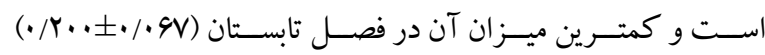

مشاهده شد (شكل 9).

بـا دسـت يـافتن بـه يافتههـاى علمسى در دهـهــاى اخيـر دانش شناخت غدد درونزيز بـا تغيـرات اساسى وارد مرحلـه نوينى شـده است بهطورى كه كنترل هورمونى بـه عنوان يـك ابز ار كارامـد در

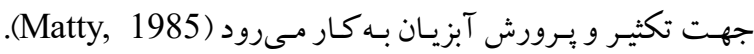
مطالعات نشـان داده كه نوسانات سالانه هورمـونهـاى اسـروئيدى

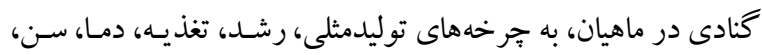




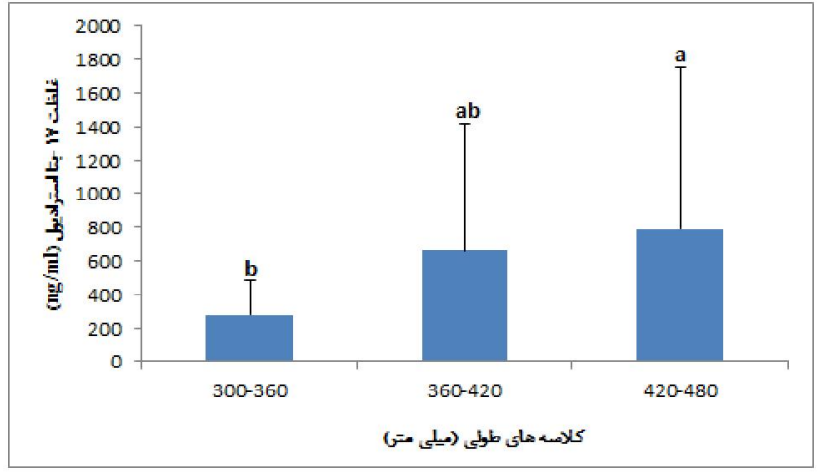

شكل 1 - تغييرات غلظت هورمون VIV-بتا استر اديول در كلاسهاى طولى (ميانخين انحر اف معيار) مولدين اردك ماهى.

Fig. 1. Changes of $17 \beta$-estradiol (mean \pm SD) in longitudinal classes of pike brood stocks.

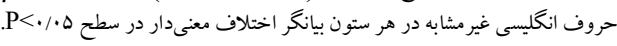

Different letters in the same column indicate a significant difference $\mathrm{P}<0.05$.

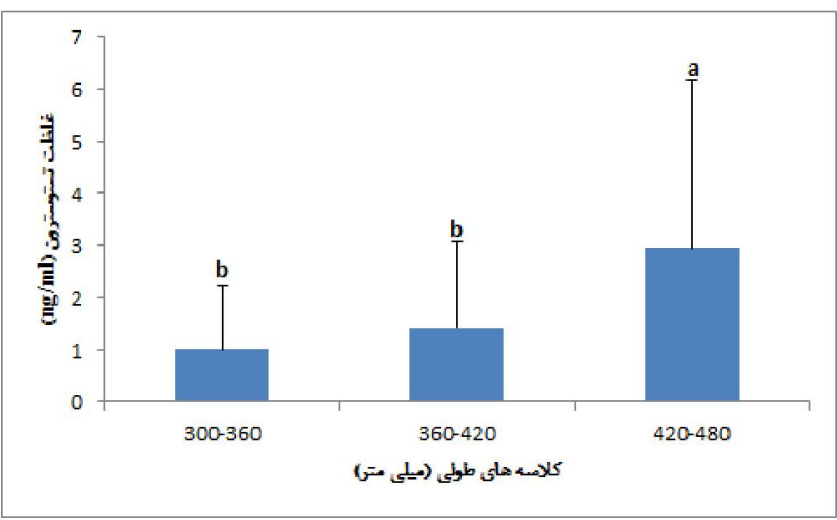

شكل r - تغييرات غلظت هورمون تستوسترون در كلاسههاى طولى (ميانكين土 انحراف معيار) مولدين اردك ماهى.

Fig. 2. Changes of testosterone (mean $\pm \mathrm{SD}$ ) in longitudinal classes of pike brood stocks.

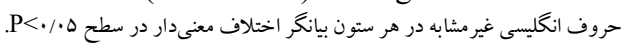

Different letters in the same column indicate a significant difference $\mathrm{P}<0.05$.

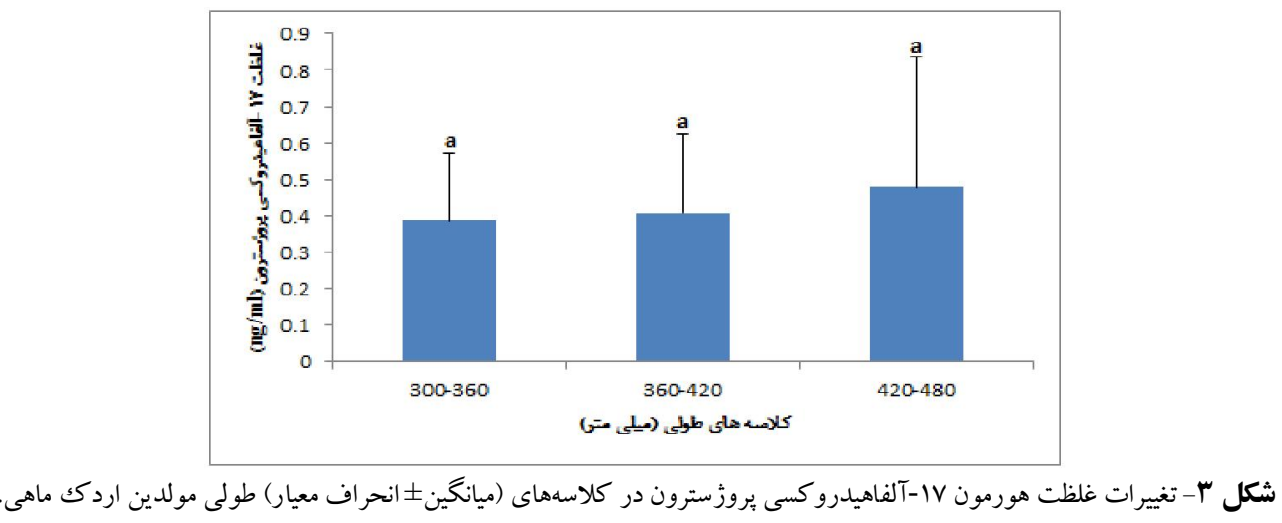

Fig. 3. Changes of 17 $\alpha$-hydroxy progestrone (mean \pm SD) in longitudinal classes of pike brood stocks.

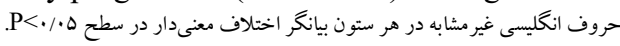

Different letters in the same column indicate a significant difference $\mathrm{P}<0.05$. 


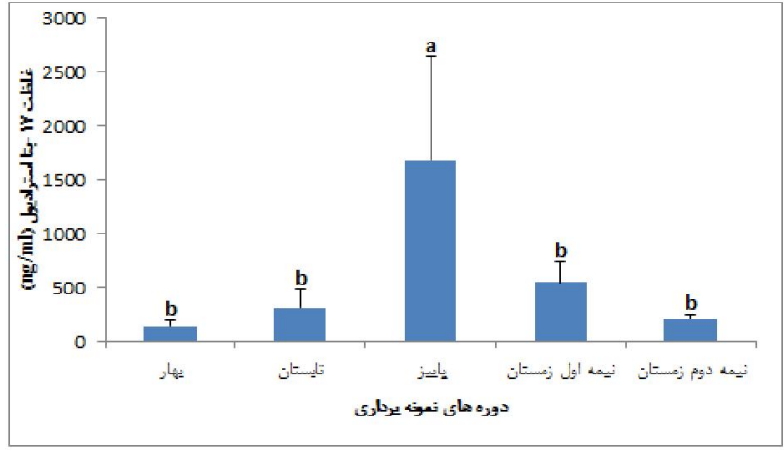

شكل ع- تغييرات غلظت هورمون IV-بتااستر اديول (ميانخين I انحر اف معيار) در فصول مختلف مولدين اردك ماهى.

Fig. 4. Changes of 17 $\beta$-estradiol (mean \pm SD) in different seasons of pike brood stocks.

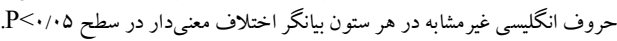

Different letters in the same column indicate a significant difference $\mathrm{P}<0.05$.

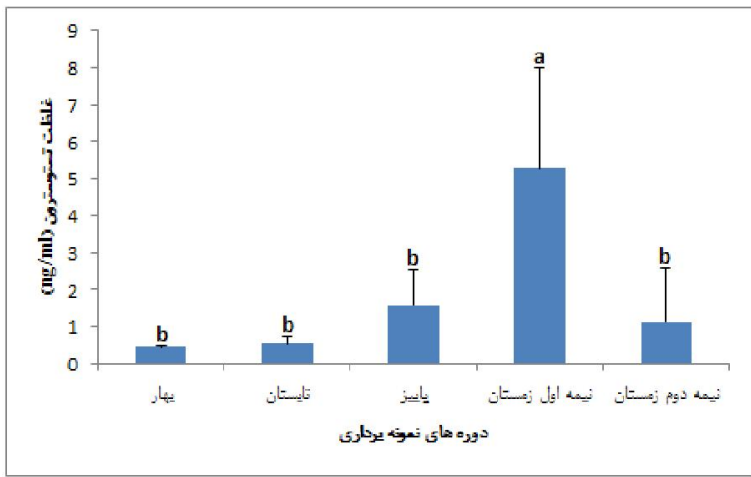

شكل 0- تغييرات غلظت هورمون تستوسترون (ميانكين ذانحر اف معيار) در فصول مختلف مولدين اردكك ماهى.

Fig. 5. Changes of testosterone (mean $\pm \mathrm{SD}$ ) in different seasons of pike brood stocks.

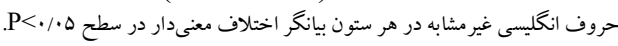

Different letters in the same column indicate a significant difference $\mathrm{P}<0.05$.

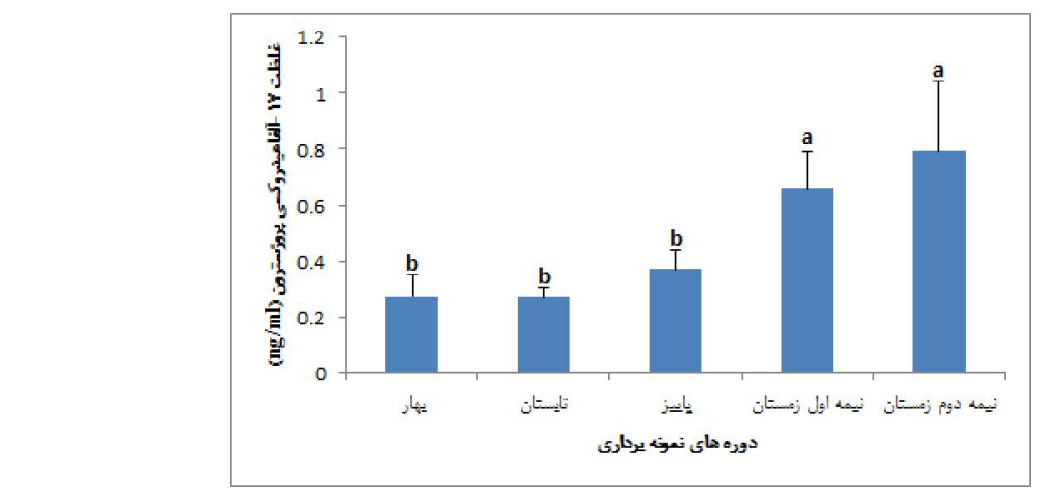

شكل 7 - تغيير ات غلظت هورمون VI آكلفاهيدرو كسىيروزسترون (ميانگين انحر اف معيار) در فصول مختلف مولدين اردك ماهى.

Fig. 6. Changes of $17 \alpha$-hydroxy progestrone (mean \pm SD) in different seasons of pike brood stocks. حروف انخليسى غير مشابه در هر ستون بيانخر اختلاف معنىدار در سطح

Different letters in the same column indicate a significant difference $\mathrm{P}<0.05$. 
اسـتر اديول در قبـل از تخــمريـزى و در زمـان زردهسـازى اسـت و .

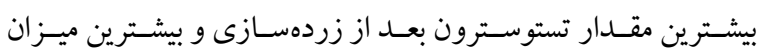

يروزّسـترون در زمــان بلـوغ جنسـى و فصـل تخــمريـزى اســت.

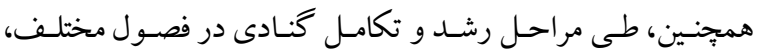

تغييراتى در ميزان و نوع هورمونهاى جنسى موجـود در سـرم خـون

ماهيـان رخ مسى دهـــ. بنـابر اين، نوسـانات هورمــونهــاى جنسـى

استروئيدى مى تواند بهعنوان شاخصى از فعاليـت جنسى در مـاهى هـا

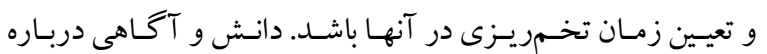

استروئيدهاى جنسى مسى توانــ باعثث سـهولت توسعه و روشهـاى

كنترل توليدمثل ماهيـان شــ؛ و همجينـين، رانـدمان حفـظ، بازسـازى،

$$
\text { تكثير و برورش اين ماهيان ارزشمند را افزايش داد. }
$$

\section{سياسگز ارى}

بدين وسيله از مهندس حميده ذكريـائى و مهنـدس فاطمـه حسين يـور دلاور از دانشـكده شـيلات و محـيط زيسـت دانشـكاه علـوم كشاورزى و منابع طبيعى گر گان، قدردانى مى گردد.

\section{REFERENCES}

Abbasi, F., Oryan, S. and Matin Far, A. 2008. The changes in sex hormones during ovarian development stages of Epinephelus coioides in Persian Gulf. Iranian J. Res. Dev. Lives. Aquac. 79: 72-80.

Abbasi, F., Oryan, S. and Matin Far, A. 2007. Interaction of ovarian development and gondal hormons in Epinephelus coioides in Persian Gulf. Pajouhesh and Sazandegi 79: 72-80.

Abdali, A. and Naderi, M. 2008. Role of rivers in biodiversity of the Caspian see fish conservation. The First Conference of National-Regional of the Caspian Sea Ecology, $11^{\text {th }}$ and $12^{\text {th }}$ June, 8pp

Agahama, Y.N. and Yamashita, M. 2008. Regulation of oocyte maturation in fish. - Devlop. Growth. Differ. 50: 195-219.

Aremen, T.A. and Gay, C.V. 2000. Simultaneous detection and functional response of testosterone and estradiol receptors in osteoblast plasma membranes. J. Cell. Bio. 79: 620-627.

Berg, A.H., Thomas, P. and Olsson, P.E. 2005. Biochemical characterization of the arctic chars (Salvelinus alpinus) ovarian progestin membrane receptor. - Repro. Bio. Endo. 3: 58-64.

Drummond, A.E. 2006. The role of steroids in follicular growth. - Repro. Bio. Endo. 4: 12-16.

Epler, P., Euszczek-Trojnar, E., Socha, M., Szcz-erbik, P., Sokoowska-Mikoajczyk, M. and Popek, W. 2008. Growth rate and histological picture of the gonads in pike, Esox lucius and pikeperch, Sander lucioperca, from the tresna reservoir (Lake Ywieckie). - Arc. Pol. Fish. 16 Fasc, 2: 147-154.
طول سال داراى اخـتلاف و بيشـترين سـطوح آن قبـل از تخــمريـزى بوده است. ميزان هورمون تستوسترون مولـدين اردككمـاهى در نيمـهـ اوّل زمسـتان، مرحلـه IV رسـيدگى جنسـى و يـس از زردهــازى، بيشتر از ساير فصسول بـوده اسـت. ايـن نتـايج بـا بررسى Sulistyo و

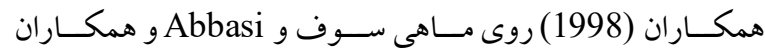
(2007) روى هـامور معمـولى مطابقـت دارد. Abbasi و همكـاران (2007) در بررسى روى ماهى هامور معمولى، ارتبـاط بـين هورمـون

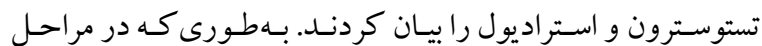
ابتدايى بلوغ نهايى اووسيتها، همزمان بـا افز ايش GTH-II كيـزان

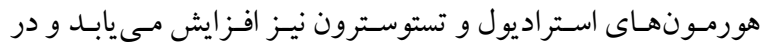
مراحل بايـانى بلـوغ نهايى اووسـيت (مرحلـه جهـار جنسىى) ميـزان استر اديول كاهش و تستوسترون افز ايش مسىيابــ. در مرحلـه قبـل از تخمريزى كه ميزان هورمون اسـتراديول افزايش مسىيابـ، هورمـون

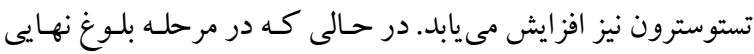
اووسيتها، ميزان استراديول كاهش ولى ميـزان تستوسـترن افزايش مى يابد. در بررسى حاضر روى اردكك ماهى نيز نتيجه مشـابه بدست

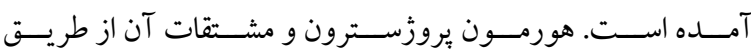
كُادوترويينها روى سلولهاى فوليكولى تخمدان سـنتز مسىشـوند و با تأثير بر بلوغ اووسيت ها عمل خـود را نشـان مس دهنـــ نتـايج ايـن تحقيـق نشــان داد كــه بيشـترين ميـز ان بروزّسـترون در نيمـهـ دوم زمستان، مرحله V رسيدكى جنسى اسـت. بـهـور كلى، ميـزان ايـن هورمون در زمان ويتلوزنز و در زمان تخمك گحذارى كه اووسيت ها در مراحل نهايـى بلوغ هسـتند، زيـاد اسـت. مشـابه ايـن نتيجـه در بررسى Abbasi و همكاران (2007) روى مـاهى هـامور معمـولى و Shafiei Sabet خزر بدست آمد. بنابر اين، مىتوان از يروز سترون بـهعنوان شاخصى بـراى تشخيص مرحله V رسـيد كى از مراحل ديخـر استفاده كرد

.(Kousha et al., 2009)

با توجـه بـه مطالعـه انجـام شــد، مسىــوان بيـان كـرد كـه اردك ماهى داراى تخمريزى يكباره بوده و روند تكاملى گنـاد بـه گونـهاى است كه در فصل بهار يس از تخـمريسزى، گنادهـا دوبـاره شـروع بـه

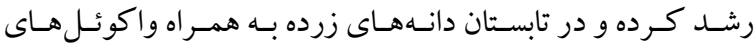
حاصل از فصل بهار مشاهده مسىشوند. همجنـين اواسـط فصل يـاييز زردهسازى كامـل مـى گـردد و تخـمريـزى در اواخــ فصـل زمسـتان صـورت مسى گيـرد (Epler et al., 2008). بيشـترين ميـزان 
Johnson, A.K., Thomas, P. and Wilson, J.R. 1998. Seasonal cycles of gonadal development and plasma sex steroid levels in Epinephelus morio a protogynous grouper in the eastern Gulf of Mexico. J. Fish. Bio. 52: 502-518.

Katz, Y. and Eckestein, B. 1974. Changes in steroid concentrations in blood of female Tilapia aurea (Teleostei, Cichlidae) during initiation of spawning. J. Endo. 95: 963-966.

Kousha, A., Askarian, F., Yousefian, M., Ghate, H.V. and Ghole, V.S. 2009. Annual fluctuation of sex steroid hormones in pre-spawning female kutum (Rutilus frisii kutum). - World. J. Fish. Mar. Sci. 1: 65-73.

Lee, W.K. and Yang, S.W. 2002. Relationship between overian development and serum levels of gonadal steroid hormones and induction of oocyte maturation and ovulation in the culture female Korean spotted sea bass (Lateolabrax maculates) (Jeomnongeo). Aquacu. 207: 169-183.

Li, L.G., Liu, X.Ch. and Lin, H.R. 2007. Seasonal changes of serum sex steroids concentration and aromatase activity of gonad and brain in red spotted grouper (Epinephelus akaara). - Anim. Repro. Sci. 99: 156-166.

MacKenzie, D.S., Thomas, P. and Farrar, S.M. 1989. Seasonal changes in throid and reproductive steroid hormones in female channel catfish (Ictalurus punctatus) in pond culture. - Aquacu. 78: 63-80.

Matty, A.L. 1985. Fish Endocrinology. - Croom Helm London, $160 \mathrm{pp}$.

Miura, T., Yamauchi, K., Takahashi, H. and Nagahama, Y. 1991. Hormonal induction in all stages of spermatogenesis in vitro in the male Japanese eel (Anguilla japonica). - Proc. National. Acad. Sci. 88: 5774-5778.

Nagahama, Y. 1994. Endocrine regulation of gametogenesis in fish. - Int. J. Dev. Bio. 38: $217-$ 229.

Nagahama, Y., Matsuhisa, A., Wamatsu, T., Sakai, N. and Fukaoa, S. 1991. A mechanism for the action 01 pregnant mare serum gonadotropin on aromatase activity in the ovarian 10Uicie of the medaca, Oryzizs latipes. - J. Exp. Zool. 259: 53-58.

Nagahama, Y., Goshikumi, M., Yamashita, M., Sakai, N. and Tanaka, M. 1993. Molecular endocrinology of oocyte growth and maturation in fish. - J. Fish. Physiol. Bio. 11: 3-14.

Pavlidis, M., Greenwood, L., Mourot, B., Kokkari, C., Le Menn, F., Divanach, P. and Scott, A.P. 2000. Seasonal variations and maturity stages in relation to differences in serum levels of gonadal steroids, vitellogenin and thyroid hormones in the common dentex (Dentex dentex). - Gen. Com. Endo. 118: 1425.

Poortenaar, C.W., Hooker, S.H. and Sharp, N. 2001. Assessment of yellowtail king fish (Seriola lalandi lalandi) reproductive physiology, as a basis for aquaculture development. - Aquacul. 201: 271-286.

Semenkova, T., Barannikova, I., Kime, D.E., Mc Allister, B.G., Bayunova, L., Dyubin, V. and
Kolmakov, N. 2002. Sex steroid profiles in female and male stellate sturgeon (Acipenser stellatus) during final maturation induced by hormonal treatment. - J. Appl. Ichthyol. 18: 375-381.

Shafiei Sabet, S. 2008. Effects of fish size and seasonal on gonadal steroid hormones and sexual maturation in brood stock of Rutilus frisii kutum. - Master's thesis, University of Agriculture Science and Natural Resources, Gorgan, Iran, pp: 96-102.

Shafiei Sabet, S., Imanpoor, M.R., Aminianfatide, B. and Gorgin, S. 2008. The study on some blood ionic and metabolic parameters in maturated and immature female's kutum (Rutilus frisii kutum) migrated to Sefid-rud estuary. - Vet. J. 84: 71-79.

Silversand, C., Johan Hyllaner, S. and Haux, C. 1993 Isolation, immunochemical detection and observations of the instability of vitellogenin from four teleosts. - J. Exp. Zool. 6: 587-597.

Sulistyo, I., Rinchard, J., Fontaine, P., Gardeur, J.N., Capdeville, B. and Kestemont, P. 1998. Reproductive cycle and plasma levels of sex steroids in female Eurasian perch (Perca fluviatilis). - Aqua. Liv. Resour. 3: 101-110.

Taghizadeh, V., Imanpoor, M.R. and Mehdinejad, N. 2013. Study the seasonal steroid hormones of common carp in Caspian Sea, Iran. - World J. Fish. Mar. Sci. 5: 282-285.

Vosoughi, G. and Mostajir, B. 2000. Freshwater fish. Tehran University Press, $317 \mathrm{p}$.

Yooneszadeh, M., Fiezbakhsh, H., Bahmani, M., Kazemi, R., Pourdehghani, M., Ghaysar Karimlo, R., Mohammadian, T. and Saeidi, S. 2008. Sequential of sex steroids and cortisol levels in farmed stellet sturgeon (Acipenser stellatus) female brooders after induced ovulation by GnRH (Oca-Fact III). - Fish. J. 3: 1-9.

Yousefian, M. and Laloei, F. 2011. Genetic variations and structure of common carp (Cyprinus carpio) populations by use of biochemical, mitochondrial and microsatellite markers. - Middle-East J. Sci. Res. 7: 339-345.

Yousefian, M., Sheikholeslami Amiri, M., Hedayatifard, M., Dehpour, A.A., Fazli, H., Ghiaci, M., Farabi, S.V. and Najafpour, S.H. 2010. Serum biochemical parameter of male and female rainbow trout (Onchorhychus mykiss) cultured in Haraz River, Iran. - World J. Fish. Mar. Sci. 2: 513-518.

Zaprudnova, R.A. and Prozorovskaya, M.P. 1999. The change in concentrations of catecholamines and ions in tissues of Bream (Abramis brama) under stress. J. Ichthyol. 39: 262-266.

$$
* * * * *
$$

How to cite this article:

Imanpoor, M.R., Taghizadeh, V., Khodadoust, A. and Roohi, Z. 2018. Effect of fish size and seasonal changes on gonadal steroid hormones in pike brood stocks (Esox lucius). - Nova Biologica Rep. 5: 65-71.

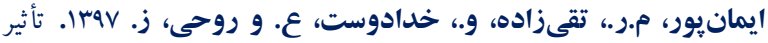

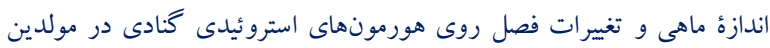

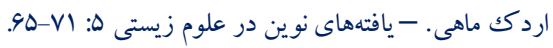

